\title{
Later-Life Learning and Older Women Learners: A Feminist Commentary
}

\section{Marvin Formosa}

\begin{abstract}
Later-life learning continues to remain well under the radar as far as feminist theorising and empirical research are concerned. This exclusion is surprising considering that older women make up the majority of learners in later-life learning programmes. This essay has three objectives: to present the available knowledge on older women and learning given that this information remains undocumented; to apply a feminist critique to the mainstream literature on older adult learning, with a special reference to the University of the Third Age (U3A) and Women's Institutes (WI); and to promote an understanding of the similarities and diversities of older women by highlighting the significance of socially diverse factors such as class, ethnicity, and age in shaping their learning experiences or lack thereof. In an ageing society, organisations such as U3As and WIs have the potential to improve the quality of life of older women and the overall community in which they live. However, their role in enabling older women to attain some level of critical consciousness by leading them to reflect on everyday realities and analyse the relationships between personal contexts and the wider social forces of marginalisation was found to be marginal at best.
\end{abstract}

Keywords: older women, later-life learning, feminism, University of the Third Age

Formosa, Marvin. 2021. Later-Life Learning and Older Women Learners: A Feminist

Commentary. Gender a výzkum / Gender and Research 22 (1): 178-200, http://dx.doi.org/10.13060/gav.2021.007.

Recent decades have seen considerable academic attention devoted to the impact of gender relations on adult learning and human ageing. While feminist educators have highlighted how males' positionality as the promoters of ideas is responsible for the masculinist tendencies in theories and practices in adult education (Zarestky et al. 2019), feminist gerontologists have recorded the experiences of older women to theorise gender relations as power relations that are embedded and institutionalised in social arenas and that have vital consequences for the life chances of ageing women (Hooyman 2018). Yet, it is regrettable that later-life learning has remained 
well under the radar as far as feminist theorising and empirical research are concerned (Formosa 2019a). Although back in the mid-1990s it was noted that 'there remain few areas of scholarly activities untouched by critical feminist interventions' (Rogers 2006: 189), twenty-five years later the sub-field of older adult learning remains steadfastly immune to gender and feminist inferences. On one hand, educational gerontologists dedicated scant attention to older women's experiences and trajectories. Despite the considerable interest in learning among older men observed in the new millennium, largely as a result of the successful global travails of Men's Sheds (Carragher, Golding 2015), feminist and women-friendly approaches have remained scarce. On the other hand, feminist educators and gerontologists alike have overlooked the question of older adult learning. While the attention of the former has remained narrowly focused on the middle-age phase of the life course, the preoccupation of the latter has been restricted to the issue as a 'social problem', with a focus on the ways in which older women tend to be poorer, more vulnerable to abuse, and severely lacking in access to affordable health care. Such exclusionary trends in older adult learning are highly surprising considering the heavily gender-biased rates of participation, as it is common for older women to outnumber men by three to one in some later-life learning programmes, where at times they even make up as much as $80 \%$ of the student body (Ware 2013).

This essay was intended to address the prevailing lack of feminist debate on later-life learning and older women learning. 'Its impetus arose from both my long-standing personal engagement with radical approaches to education and learning and from my agreement with Leathwood and Francis's opinion (2006: 2) that the 'policies and practices of lifelong learning ... are gendered in their construction and effects'. This has resulted in a very limited understanding of older women's learning amongst adult educators and educational gerontologists, so that many learning practices with older women continue to be based on obsolete or, in the worst-case scenario, on 'malestream' information and perspectives. Although a number of studies on older adult learning did draw on the life history of learners (Broecher, Davis, Painter 2017), few incorporated feminist outlooks on education and ageing (Kamler 2006; Wilińska 2016). This is warranted because women's learning must be understood and valued in its own right and within a broader social context that encompasses the social determinants of gender roles and norms (Leavy, Harris 2019). Indeed, learning practices with older women lose much of their efficacy if facilitators remain unaware or insensitive to how society, for instance, systemically denigrates older women, excludes them from the mainstream of educational opportunities and productive life,

\footnotetext{
1 Acknowledgements: I sincerely thank the two anonymous reviewers whose comments and suggestions helped to substantially improve and clarify this paper.
} 


\section{ESEJ / ESSAY}

and judges them primarily in terms of their appearance and declining skills (Withnall 2009).

The objectives of this essay were threefold. The first objective was to compile an exposition of the available knowledge about older women and their learning, given that this information remains undocumented. The second endeavour was to apply a feminist critique to mainstream literature on later-life learning, with a special reference to the University of the Third Age (U3A) and Women's Institutes (WIs), which are two of the most successful institutions involved in older adult learning. Finally, the essay sought to promote a cultural understanding of the similarities and diversities of older women by highlighting the significance of such factors as class, ethnicity, and age in shaping their learning experiences and opportunities or lack thereof.

\section{Feminist education and later-life learning}

Cultural critic and feminist theorist bell hooks (2000: vii) defined feminism as a 'movement to end sexism, sexist exploitation, and oppression'. However, feminism is a highly contested concept. There are many strands of feminist education, and different models have adopted different theoretical standpoints. For instance, the psychological model prioritised the creation of learning support networks that enable women to speak about their experiences and see themselves as 'knowers' who are capable of producing knowledge (Belenky et al. 1986). While this approach was lauded for foregrounding learners' experiences as women and emphasising affective as well as rational knowing, its individualistic orientation implied a complete lack of attention to race, ethnicity, and class differences, and hence failed to account for differences between women or differences in power relations based on various positionalities. In response, other feminists adopted a structural outlook that both built upon and went beyond Freire's (1970) focus on class so as to deal also with gender, race, and sexual orientation (Luke, Gore 1992). Extolled for its attention to the learners' diverse positionality resulting from unequal power relations, such a turn was nevertheless criticised for downplaying the individual's capacity for agency. In Tisdell's (1996: 310) words, such theories 'focus too much on structures, and do not account for the individual's capacity for agency, the capacity to have some control outside of these social structures'.

One possibleway to transcend the limitations of such models is provided by poststructural feminism, which forms a synthesis of the psychological and liberatory models to promote both personal emancipation and public action. The poststructural approach is able to account for all four recurring themes that underlie feminist pedagogy: how knowledge is constructed, the development of voice, the authority of students and teachers, and addressing differences (Formosa 2005). A poststructural feminist perspective 
...would emphasize the importance of relationship and connection to learning, but also account for the fact that power relations based on a multitude of factors including gender, race, and class are always present in the learning environment and affect both how knowledge is constructed on the individual level as well as the social and political factors that affect as what counts as 'official' knowledge and how it is disseminated.

(Tisdell 1996: 311)

This perspective devotes attention to the role of power in how knowledge is shaped and disseminated in the classroom and, perhaps more importantly, in society at large by recognising how the self constructs knowledge in relation to others, and how both the self and others are situated and positioned within social structures that are simultaneously privileged and oppressed. Poststructural feminism strives to give a 'voice' to those who have been traditionally marginalised in adult education. It also problematises the power and authority of the teacher and considers the potentials and ramifications of the learning event for redistributing power. Finally, it addresses both the differences and similarities of learners by using participants' autobiographical and life experiences, rather than falling into the trap of homogenising all women as equally oppressed, which is usually the case in critical pedagogy.

Bearing in mind that feminist thought has had an interest in/has been discussing adult education since the 1980s and that the first studies on the 'double jeopardy' of ageing and gender emerged in the early 1970s, one would expect the field of later-life learning to long ago have incorporated a sensitivity to gendered and feminist considerations. Regrettably, this failed to materialise, and to date there have been few analytical and empirical attempts to apply a feminist lens to later-life learning. One early foray in this respect was Meade and Walker's (1989: 181) criticism of pre-retirement learning initiatives for adopting a male 'gaze' by assuming that later life is a 'time of personal freedom and choice', when for older women the work of household chores and caring continues and may even intensify as husbands and other members in the extended family become frail. Similarly, Harold (1992: 515) argued that although learning programmes designed for later life are based on a personal growth concept and are therefore an excellent means for facilitating social participation and personal development, they 'fall far short in being instrumental in significantly altering the well-being of aging women or changing either personal or societal concepts about old age and older women'. She also rejected the malestream assumption behind the functionalist rationales for older adult learning that the role-discontinuity of retirement is something that only affects men, while the real crisis that affects women is widowhood. She thus advocated for later-life learning to distance itself from objectives that prioritise individual learning or development 'tasks' and instead 


\section{ESEJ / ESSAY}

to adopt strategies that initiate 'both personal and social change in quality-of-life issues related to women's aging process' (Harold 1992: 519).

Researchers also examined the choices and constraints that older women experience in accessing learning by focusing on the lifelong learning programmes organised by the National Federation of Women's Institutes (NFWI). Founded in the United Kingdom in 1915, at the end of 2019 the NFWI (2019) included 69 regional federations, 6,300 WIs, and a membership of 208,464 women in 201 WIs, the majority of whom were aged $50+$. The NFWI offers 'women the opportunities to make an impact in their communities, to influence local, national and world issues affecting the social, economic and environmental life of families and communities, and to learn traditional and new skills' (Jackson 2006: 75). Since 1948, the NFWI has managed Denman College as its residential academy to run a wide variety of educational courses, which last from two to four days and range from 'personal development' programmes focusing on beauty and fashion to modules on social studies, history, and public affairs ${ }^{2}$ (Beaumont 2018). A qualitative study found that older women learners value Denman College as a 'safe space' and an opportunity to acquire knowledge and new skills, something that was particularly appreciated during difficult times such as retirement and widowhood, as such activities helped them to gain confidence, develop new interests, and build their social networks (Jackson 2005, 2006, 2012). Nevertheless, the same study also claimed that most learning initiatives served to anchor older women in gendered expectations about traditional roles:

Women are taught how to dress and wear make-up as well as how to undertake a host of feminine arts and crafts. And they are taught how to enhance their cooking skills, the better to produce that homemade jam. Learning these things makes women more fulfilled, and enables them to be better wives and mothers (despite the fact that none of them are likely to have children at home).

(Jackson 2006: 85)

The learning experience at Denman College was also criticised for approaching older women as a homogenous group characterised by middle-class (gendered) identities and for remaining relatively insensitive to the fact that older women are more vulnerable to poverty, social exclusion, and morbidity compared to their male

\footnotetext{
2 In July 2021, the NFWI Board of Trustees issued a statement announcing the closure of Denman College owing to financial problems caused by the three-month closure during the COVID-19 lockdown period (NFWI 2020). In its stead, the NWFI (n.d.) launched the 'Denman at Home' website, where members can book and participate in a range of virtual learning programmes.
} 
peers (Jackson 2006, 2012). Indeed, no attempt was witnessed at WIs to mitigate the fact that older women learners continued to be constrained by the gendered and traditional constructions of them as wives and mothers that defined them when they were younger. As a result, Etienne and Jackson (2011a, 2011b) were sceptical that the positive benefits of the learning programmes at Wls were being experienced by a growing ageing population characterised by loneliness, isolation, and social exclusion. They concluded that in retirement the choices that exist for older women learners (still) 'are largely influenced by family responsibilities, money, networks of support as well as the expectations of the wider community' (Etienne, Jackson 2011b: 239).

\section{Older women learners}

Research has also focused directly on the experiences and benefits of learning among older women. Hiemstra (1993) argued that older women learners differ markedly from their male peers of the same age and from younger women in that they are more likely to be self-directed, be interested in self-fulfilment learning, and express a preference for liberal over vocational learning subjects. Similarly, McFadden and Atchely (2001) reported that older women learners set high goals for themselves and require consistent affirmative feedback from their instructors. Kamler (2006) threw cold water on mainstream lifelong learning policy by pointing out that its emphasis on employability, jobs, and working lives was at odds the inclusive goal of widening participation to include people - such as older women - who had previously prevented from taking up learning opportunities because of social and economic constraints. In an attempt to reverse this situation, she launched a lifelong learning project that engaged older women in Australia in the processes of writing, public speaking, performing, and film-making, and provided an inspiring account of the potential and benefits of learning for achieving social transformation in older women's lives. In her own words, the project

... produced change in the older women's lives. Meeting together in the workshops the women found a community of survivors, a space of friendship and laughter and a place to be taken seriously as learners. But the narrative work also had significant material effects on the older women's sense of wellbeing and survival. Through the process of physically remaking stories of ageing in film, writing and performance, many women began to rewrite themselves as well as their texts.

(Kamler 2006: 160-161) 


\section{ESEJ / ESSAY}

In direct contrast to the ominous warnings about the burdens that an ageing population is having on public welfare programmes, Maidment and Macfarlane (2011) documented the contributions of a resilient and committed group of Australian older women to community fundraising, building social networks, and providing each other with learning opportunities. The benefits went well beyond the customary ones that revolve around learning craft-making skills, like the 'mutual sharing of resources such as knitting and sewing patterns and specialist equipment, car pooling, recipes, health information, home maintenance help, financial tips, and hospitality" imbued participants with higher levels of social capital' (Maidment, Macfarlane 2011: 287).

Survey research on the perceived motivations and benefits on behalf of older learners also found distinct patterns of difference due to the influence of gender. In Germany, Sagebiel (2006) distributed a questionnaire amongst current students and past alumni of a 'senior course of studies' at the University of Wuppertal and found that many older women became motivated to get involved in learning following some life crisis - for example, retirement, children leaving the family home, a serious illness, and/or becoming a widow. Remarkably, as many as $45 \%$ of married women pointed out that they were often prevented in pursuing their wish to start learning something by their husbands and by the gendered role expectations of their families, so it would have been a struggle to attend classes. Interestingly, older women were not only discouraged by family expectations but also by women in their social network of the same age who preferred to interact with family members and significant contacts rather than generalised others. Sagebiel revealed various gendered differences in learning:

The female mode of learning concentrates as much on achievement in subject matters as on creating a communicative learning atmosphere, while men concentrate solely on their own performance. Although interviews and observations have shown that women and men often suffer from similar learning difficulties, men seldom talk of any learning problems or weaknesses while women demonstrate a willingness to reflect upon their perceived limitations. (Sagebiel 2006: 354)

Similarly, Narushima, Liu and Diestelkamp's survey (2013) found that older women were generally more enthusiastic and appreciative of the opportunity to engage in later-life learning, and generally favoured crafts and fitness classes over courses related to practical knowledge and skills such as information and communication technology. In the authors' view, this was because: 
...older women feel freer and want to learn something new for joy and selfrealization in group settings, which reflects traditional gender life course and socialization ... it should be underscored that practical and social motivations and benefits (e.g., to keep myself physically active, to take courses with affordable fees, to meet new people and make friends, I found learning keeps me going in difficult times) were far more frequently reported by women in this study. This implies that women may use the program as a coping strategy as well.

(Narushima Liu Diestelkamp 2013: 582)

Universities of the Third Age (U3As) have also been the subject of numerous research initiatives in the past two decades, and this has included a focus on gendered patterns and older women in U3As (Formosa 2019b). The first U3As were founded in France in $1973^{3}$ and can be defined as 'socio-cultural centres where senior citizens may acquire new knowledge of significant issues, or validate the knowledge which they already possess, in an agreeable milieu and in accordance with easy and acceptable methods, with the objective of preserving their vitality and participating in the life of the community' (Midwinter 1984: 18). Although the organisers of U3As are at liberty to do so in the way that works best for them, there are two main U3A models. While U3As that follow the Francophone model form part of a traditional university set-up and are thus able to make use of its premises, human resources, and financial funds, others that follow the Anglophone model are independent, autonomous, and based on the 'mutual-aid' principle 4 (Formosa 2014).

Williamson's (2000) research at the Liverpool U3A found that older men and women approached later-life learning very differently. Whilst men were inclined to adopt an indifferent approach to learning in later life, women deemed later-life learning an opportunity to do things denied them during middle age. In Williamson's words,

\footnotetext{
3 The U3A movement has not only withstood the test of time but has also witnessed a substantial increase in the number of centres and members all over the globe (Formosa 2019b). Although comparative statistics are lacking, Australia had some 300 U3As, with a membership of around 100,000, whilst its neighbour New Zealand has 84 U3As, with the members of the 25 Auckland U3A communities numbering 3,719 in 2017. Figures for Britain reached over 1,000 U3As (400,000 members) in 2018, and a 2013 Interest Group Survey revealed that there are more than 36,000 U3A interest groups in the region. In the Asian continent, China alone included 60,867 U3As and around 7,643,100 members in 2015.

${ }^{4}$ Irrespective of the model adopted, the differences between U3As and WIs are unmistakable. The WI was developed as a feminist movement that 'has provided a significant space for feminist activity since its formation 100 years ago' (Andrews 2015: 11), as surely evidenced by their campaigns for the rights of single mothers and illegitimate children, and for the recognition of rape within marriage (Robinson 2012). The U3A, on the other hand, is unapologetically 'non-political' (Third Age Trust n.d.) and 'non-sectarian', and centres do not take a public stance on any contentious contemporary issues such as climate change or ageing-related concerns such as pensions and euthanasia (Formosa 2019b).
} 


\section{ESEJ / ESSAY}

Some women, once they lose their husbands, become free, come to life, and like to do many of the things they've wanted to all their lives and haven't been able to... They had been drawn toward the further learning which U3A courses afforded them for reasons associated with their own life histories including lost educational opportunities, child rearing and domestic responsibilities, a need to get out and do things...

(Williamson 2000: 56)

Many of the women interviewed by Williamson pointed out that being in the third age gave them a great sense of freedom since they had had fewer opportunities than men to pursue their interests outside the home prior to retirement, despite their wanting to participate in a diversity of social and cultural activities. As in Sagebiel's (2006) study, a number of older women learners confessed how they had to overcome their husbands' as well their own misgivings in order to get a break from domestic life, where a wife can 'go out and not be at home for a meal' (Williamson 2000: 60). Another obstacle that prevented older women from enrolling and participating in the U3A was their limited education - what Lamb and Brady (2005) called the 'education begets education phenomenon' - as older persons with higher levels of education (and financial security) tend to return to continue their learning journey well into retirement. Another study on older women attending a U3A situated in Malta found that despite being more numerous in the classroom, they still tended to be less visible than male learners, who tended to dominate the discussion even when in the minority ${ }^{5}$ (Formosa 2005). Most women voiced their discontent at the fact that most educators organised the learning sessions in 'teacher-led' ways and they disliked being 'treated like kids' when they possessed a wealth of life experience and diversity (Formosa 2005: 404). This led Formosa (2005: 404) to infer that third-age

${ }^{5}$ Given that this article will make multiple references to studies on the University of the Third Age in Malta, we should here add a note to help explain the role of women in Malta in a socio-cultural context (Formosa 2015). Until the new millennium, and thus for most of older women's lives, Malta subscribed strongly to the so-called 'southern model of welfare', which means that since state provision for care is marginal, people are dependent on female relatives for care. The fact that Malta is also a Catholic country and strongly influenced by male-dominated trade unions, this 'familialism' coincides with a strong 'male breadwinner model'. Suffice it to say that although the marriage bar to working after marriage was lifted in 1979, women re-entering the workforce (after having children) were not permitted to return to their previous grade[to a job on the same level]; the large majority of married women moreover remained inactive in the labour market either out of personal choice or due to social pressure, and it was only in the 1990s that married women began challenging the bishops' mantra that advocated 'intensive mothering'. This 'maternalist' discourse was also championed by the state, which tried to entice women to assume responsibility for caring for frail relatives by offering a 'carer's benefit/allowance' pegged at an amount equal to half the minimum wage. 
learning may emerge as a 'reflection of masculine suppositions regarding later life', and thus there is urgent need for later-life learning to 'focus on women's abilities on creating positive images and on having meaning and relevance at an individual level' (Phillips, Bernard 2001: 168).

In a ground-breaking study on older women within the context of U3As in Poland, Wilińska (2016: 334-335) declined to present them as 'void of the sense of agency that could be mobilized to mount active resistance'. During her field research, she uncovered stories of older women whose lives were transformed by the power of subjective and emotional responses to the socially imagined ways of being old. One informant, Julia, was certainly a case in point:

Shortly after she retired ... she began to panic ... for the first time, she had a lot of free time....For Julia, her work had been her main orientation... Her friends provided her with resources and helped to direct her towards a new space - the U3A. Julia saw that there was a world outside of her former workplace, that things were happening, and she wanted to be part of it. She gladly joined to realize that, 'I have found my way for the second time in my life' (the first time was when she decided on her occupation as a teacher).

(Wilińska 2016: 338)

On the basis of this and other life stories, Wilińska (2016: 342) posited that U3As mitigated against the sexist and ageist discourses that remove the bodies of older women from the public sphere by relegating them to an invisible space, and that they did this by becoming a 'space for women's activism and of embracing their womanhood'. While older women are generally stereotypically pigeonholed as grandmothers, this is only one of many roles they enjoy performing, and Wilińska's (2016: 343) study pushes gendered boundaries by demonstrating that they 'continue to enter public spaces to mark their presence and to become visible'. Although this occurs at the individual level and is not affected by the feminist emphasis on solidarity among women in an effort to challenge the gender order, Wilińska (2016) succeeds in offering a different perspective on the organisation and mobilisation of older women via the vehicle of later-life learning.

\section{The construction of knowledge and giving people a voice}

One key strategy of feminist adult education is enabling learners to 'see with a third eye', which is to say, to move away from a 'universalized mode of thought ... [to] one that is personal' (Maher, Tetreault 1994: 202). Achieving this objective involves recognising how 'social structures and power relations affect not only how knowledge 


\section{ESEJ / ESSAY}

has been produced in a society', but also 'how what has counted as "knowledge" has been determined, and by whom' (Tisdell 1998: 150). Unfortunately, past literature has shown that this has not been done in later-life learning. For instance, past and current developments in pre-retirement learning are marked by an extensive preoccupation with softening the negative effects of the so-called crisis of losing one's paid employment, and therefore, 'retirement' and 'post-employment' are treated as equivalent. Pre-retirement learning continues to be geared to the needs and interests of men and tends to exclude ageing women whose adult lives may have been circumscribed by the gendered expectation that a wife's primary responsibility is to ensure that her husband and offspring have a 'home sweet home' to return to, and who now require guidance on how to overcome these domestic boundaries, which keep them isolated and lonely in later life. The fact that most pre-retirement learning programmes occur at workplace settings (Findsen, Formosa, 2011), rather than at community centres, suggests that older women are still not take seriously as learners and as producers of knowledge. This contradicts the inclusive goals of lifelong learning, especially in terms of widening participation to people previously marginalised from educational opportunities due to social, economic, or geographical constraints. The fact that women have a longer life expectancy than men, and thus outnumber them in later life, not only makes their inclusion in the pre-retirement preparation for retirement an urgent matter, but also means that there is a need for specifically tailored programmes that do not resemble 'training courses' and a need to include women educators and women-friendly curricula and styles of presentation in these programmes.

Formosa's (2019c) comparative research of U3As in Europe and the Asian-Pacific region found that most centres follow a malestream 'banking' educational model, as if the 'students are "objects" into which teachers pour prescribed knowledge' (Freire 1998: 4). Indeed, none of the authors in this edited manuscript uncovered an attempt on behalf of educators to discuss with or prompt learners as to how sociostructural systems of privilege and oppression - such as race, ethnicity, class, religion, sexual orientation, and, most importantly for the research here, gender - impact the construction and validations of knowledge. Irrespective of the specific learning objectives and outcomes, the contribution of women was never foregrounded in the respective curricula. Formosa's $(2007,2012,2019 d)$ research observations at the Maltese U3A noted that, for instance, study-units on sociology, anthropology and criminology only presented and discussed the works and thoughts of male scholars (e.g. Marx, Durkheim, Weber, Levi-Strauss, Lombroso, etc.). The educators even went so far as to describe such theorists as the 'founding fathers' of the disciplines in question, as if all the protagonists in the construction of the social sciences were men. Similarly, in learning programmes on foreign literature only books written by 
male authors were studied (e.g. Shakespeare, Dickens, Twain, Hardy, etc.), and in religious seminars the texts that were studied hinted at the mental, moral, and spiritual inferiority of women. Not only was a focus on women's rights completely absent during his observation period, but the way women were represented or portrayed was firmly entrenched in the sphere of domesticity, with the most dominant images being mothers and homemakers, and with an emphasis on (promoting?) proficiency in such (female) leisure pursuits as knitting and quilting. The automatic assumption was that whilst older men learners came to the U3A on the back of a long career in occupational enterprises, women were supposed to have spent their adulthood at home.

Putting such annotations and other research in perspective (e.g. Robbins-Ruszkowski 2017; Mackowicz, Wnek-Gozdek 2016) one finds no evidence that the U3A movement reflects the way older women's stories may even negate the 'home sweet home' images of stability by representing 'homemaking' 'as a lifelong process of change, of remaking and rebuilding after a divorce or the death of a child or spouse ... or ill health' (Kamler 2006: 158). In fact, in an earlier research Formosa (2005) noted how at the Maltese U3A older widows found themselves in double jeopardy, as they were perceived and labelled as 'unfortunate' and 'vulnerable' persons for whom the U3A served as a therapeutic activity to alleviate their loneliness and isolation. However, this perception did not apply to widowers, as men were viewed as independent and mentally and physically strong. Finally, the fact that the majority of U3A managers in Formosa's (2019e) review of European and Asian-Pacific U3As were men signifies an urgent need for what Voet (1998: 136) calls an 'active and sex-equal' citizenship, which advocates equal participation in decision-making. There is no doubt that solely ensuring the social inclusion of older women in the U3A is definitely not enough, since 'inclusivity' often means being included as part of the dominant ideology, whereby the values and experiences of marginalised groups remain ignored or rendered invisible. Of course, as one anonymous reviewer pointed out, it could be argued that the role of U3As is not to build the capacity of feminist adult education per se but to provide an opportunity for education and to inform and empower the learners. Wilińska's (2016) research is certainly a testament to this opinion and there is certainly much room for further research into this aspect through comparative studies.

Despite NFWI's commendable travails in political advocacy, Denman College still failed to deliver a 'personalised' learning experience. Despite research at Wls uncovered a willingness on behalf of women to 'share experiences', to 'get on with others', and to 'encourage others to join', Jackson $(2006,2012)$ found the learning environment was commandeered by an almost exclusively middle-class habitus. While most chairmen and women described their social class standing as 'middle' or 'professional', with very few exceptions identifying themselves as 'working-class', at the same time they 


\section{ESEJ / ESSAY}

bolstered a sense of class closure by expecting that fellow members are 'people like us'. As Bourdieu (1984) argued and demonstrated, poverty is no obstacle to middle classness, since subjects can rest on non-material resources and cultural symbols to mark their social distinction:

The middle-class habitus of both the WI and the College is embodied in the bedrooms of the College, decorated and furnished by individual Federations in styles recognised by the students at the College and enabling them to 'feel at home.' It is also one of the roles of the College chairmen to ensure that students continue to feel at home throughout their stay.

(Jackson 2006: 84)

The fact that many of the past courses on offer at Denman College were rooted in women's roles - in teaching women how to dress, wear make-up, cook, and how to undertake a host of feminine arts and crafts - testifies to a long-standing and ongoing attempt on behalf of Wls to claim the badge of respectable femininity. This should not be surprising since after the 19th century femininity became established as a (middle-) class sign: 'femininity was seen to be the property of middle-class women who could prove themselves to be respectable through their appearance and conduct' (Skeggs 1997: 99 - italics in original). This occurs because normative conceptions of middle-class women's respectability are measured by prioritising 'home life' above 'occupational careering' by perfecting domestic, care, and socialising roles. Indeed, a look at the WI's (n.d.) Denman website finds virtual learning programmes on 'paper cutting for Valentine's Day', 'cushion covers', 'ready, steady, sew', 'reversable aprons', 'daffodil wreaths', 'needle felted pictures', as many as 10 different 'cooking courses', and the so-called 'lifestyle courses' that include classes on qigong and mindful yoga. Learning such skills enables older women to be better partners, wives, and mothers despite the fact that, as Jackson (2006: 86) noted, 'none of them are likely to have children at home' - and thus to buy into a cult of domesticity that is central to the self-definition of the middle classes. A concluding note on the way that knowledge is constructed at WIs concerns the usage of the term 'chairman' to refer to the Regional Chairs, which is certainly a curious practice for a women's organisation. Jackson (2012) inquired into this practice and found that many of the women had never considered the sexist implications of applying such a word and even accepted this nomenclature since the WI was a women-only organisation. She observed no wish on the part of either the 'Chairmen' themselves or the members to change or challenge this language. At the time of writing, this terminology remains in use.

The theme of 'voice' is also key to feminist learning, since this is associated with knowledge, empowerment, and the active claiming of a transformed identity. In his 
consideration of the formal educational system, Bernstein (1996: 7) noted that 'we can ask about the acoustic of the school. Whose voice is heard? Who is speaking? Who is hailed by this voice? For whom is it familiar?' Undoubtedly, these interrogations can be levelled to the acoustics of later-life learning avenues. Formosa (2005) observed that at the Maltese U3A the division between those who speak easily and fluently, those who tend to remain silent in the learning environment, and those who are consciously recognised as either a 'follower' or a 'leader' follows the same systems of gendered privilege and exclusion. Although older women always made up three-quarters of the learners in every class, they rarely asked any questions, unlike the men, who not only frequently asked questions but also contributed comments to supplement the educators' presentations. Jackson's (2006) research at WIs uncovered similar trends. Even though developing people's political voices, both in local communities and in national campaigns, is a sacred objective of Wls, it was still observed that

... despite the occasional exposure to the personal and political in women's lives (such as in the quilt-making sessions), the women appeared to have very little recognition of constructions of gender or of feminist consciousness, with a concern that the inroads made by feminism had left women 'victims of their own success.' In a curious way, women had to take their places in their families and communities as (middle-class) women (constructed as home makers, carers and supporters) and in the wider world as surrogate men.

(Jackson 2006: 87)

Following Bourdieu's (1984) ideas on class, capital, and subjugation, Jackson (2006: 85) concluded that whilst classes at Denman College offered women the advantage of a women-only learning space, such learning opportunities also served as a mechanism for exclusion as classes and gendered expectations are '(re-)created and perpetuated in different contexts, including non-formal and informal learning'.

\section{Authority, positionality, and difference}

Feminist adult education does not advocate a relationship of equals between educator and learners. Whilst authoritarianism has no place in any critical learning programme, educators are envisaged to being able to have a level of authority over the learning process in two key ways. First, the educator should use his/her authority to, as hooks (1994: 3) argued, 'educate for the practice of freedom. Yet, there is very little literature to be found on liberatory initiatives in older adult learning, and even less on programmes that adopt women-friendly or feminist approaches. For instance, in Findsen and Formosa's (2016a, 2016b) review of older adult education 


\section{ESEJ / ESSAY}

in as many as 42 countries, none of the contributing authors noted the presence of either of these sensitivities being given any attention in the learning programmes in the countries studied. Rather, reviewers confirmed how most courses followed a traditional andragogical-liberal outlook, where older learners are asked to focus on a curriculum that has been fixed in advanced and to follow their own learning pace. In this approach, the social fabric is generally presented as being fair and meritocratic, where each individual has an equal possibility and opportunity to reach his/her objectives (Formosa 2011). This kind of learning programme fails to recognise that groups with a larger share of ethnic, class, and especially gender privilege are more often recognised and given more status in society (Formosa, Galea 2020). For instance, Formosa $(2000,2007)$ observed that at the Maltese U3A stereotypical depictions of working-class communities either presented in the learning materials/in the classroom or arising in class discussion went unchallenged by educators, and thus argued that U3As may not only fail to act as an archetype of transformative education, but may also act as yet another euphemism for a kind of glorified occupational therapy that is both conservative and oppressive and that panders to the cultural pretentiousness of the ageing bourgeoisie.

Second, educators should involve themselves and learners in 'engaged pedagogy', which means that they should take into account people's emotions and critical thinking (hooks 1994). Yet again, most geragogical literature fails to document the use of a personalised teaching approach by educators, who, on the other hand, seem to prefer to keep their emotions in check by delivering courses in an impassioned voice, are reluctant to voice support for ideas that go against the grain, and use only PowerPoint presentations as visual aids. Indeed, educators engaged in laterlife learning have only in exceptional cases been found to use the visual arts, music, or films in the learning process or to request learners to write narratives that share their own cultural story (e.g. Hallam, Creech 2016; Creely, Southcott 2020). This is unfortunate given the existing research that documents how writing and the arts have the potential to help learners become more aware of themselves and the world, see things in a fresh light, and to have not only the power to meet challenges but also to help solve them (Formosa, Cassar 2019).

A feminist approach to older adult learning requires that educators directly consider how their and the learners' own gender, ethnicity, age, class, and sexuality have an influence on teaching and learning, the ongoing construction of knowledge, and classroom dynamics. Although critical proponents of later-life learning steadfastly encourage their learners to examine the structural power relations that have affected their lives, they still refrain from problematising how they have been empowered and politicised by means of their past and present social locations. Indeed, it is only by problematising their lives and disclosing how their own gender, ethnicity, age, class, 
and sexuality influences their perception of the world, and most importantly, led to their 'teacher' status in the classroom, will educators be successful in generating group bonding and understanding, whereby learners feel 'safe' enough to find their voice, confront and deal with power relations, and join the struggle for social change and emancipation (Tisdell 1998).

Turning again to Formosa's (2000, 2007, 2012, 2019c) studies, the Maltese U3A was characterised by a middle-class, male, heterosexual, and Roman Catholic body of educators, whose discourses, as a result, reinforced a specific type of dominant knowledge and symbolic capital. The norms, values, and linguistic codes characteristic of the local working-class community, or of members of the Lesbian Gay Bisexual Transgender community, and/or of faiths other than the Roman Catholic religion were constituted as 'other'. For example, while the researcher observed that no other sexual orientation than heterosexuality was ever addressed or even mentioned in any of the social science courses, the academic year and social events began with a celebration of Catholic Mass. The academic curriculum, in fact, included a healthy number of theological study-units delivered by priests. The majority of U3A members found this positionality to be entirely normal, since it was only recently that Malta began practising the political separation of state and church by legalising divorce, cohabitation, and gay marriage. Of course, it can be risky to problematise the identity of older learners if their identity is a subaltern one, and this needs to be considered and done with the utmost sensitivity and at the right time and context. While a white, practising doctor who is heterosexual and married can safely disclose her age and be a strong advocate for the human rights of refugees and third-country migrants, it is not as easily for an unmarried and childless lesbian who suffers from depression and anxiety to disclose her sexual orientation and mental health issues and argue in favour of more LGBTIQ-friendly policies. In such situations, the authority of educators can never be overstated, as they need to assume the responsibility for establishing a 'safe' learning environment in which subaltern learners can be comfortable enough to take a risk in declaring their own marginalised social positions. Indeed, a key task of educators in feminist later-life learning is to deal with differences (as per structural feminism) rather than similarities (as per psychological feminism).

Foregrounding positionality is key to a critical engagement in women's learning since there is no universal 'women's experience'. As Haraway (1985: 72) argues, 'there is nothing about being "female" that naturally binds women' since 'being' female is 'itself a highly complex category constructed in contested sexual discourses and other social practices'. Indeed, as older women are in no way a homogeneous group - as they differ in terms of class, ethnicity, sexuality, and age - later-life learning centres tend to accommodate particular categories of women at the expense of others. For instance, studies have highlighted how the ethos of the U3A movement is 'skewed' 


\section{ESEJ / ESSAY}

towards the middle classes and those with higher levels of educational attainment (Formosa 2019f). In Patterson et al.'s study of a U3A in North-East England, learners felt that the term 'university' implied well-educated middle-class individuals:

U3A I thought was for really clever people, like university people, the middle class...I thought they'd be too clever...I mean we never went to university, so to me the word 'University' on something means well it's probably not for me. I think there's still a lot of people the same...I don't want to offend anybody, but looking at it, to me, I would say that this was aimed at more middle-class people. (U3A members, as cited in Patterson et al. 2016: 1591)

The same was true of WIs, as Etienne and Jackson (2011b: 239) noted how WI members tend to be 'highly privileged'. However, they also observed a recognition of 'difference' based on 'ethnicity', as WI members perceived Asian women as not being 'like us':

...we have an Asian lady that comes and she educated us to their way of life... We did think of setting up in an Asian community, but because of the way they work men control the money side of it and they would want the right to come... And of course the WI can't do that.

(Etienne Jackson 2011a: 55)

Despite Dadzie's (1993) unprecedented study on the lack of educational opportunities for older black people and older people in ethnic minorities, such individuals and communities continue to experience exclusionary practices in assessing meaningful lifelong learning opportunities. At the same time, later-life learning centres are generally embedded in an ageist paradigm as membership does not tend to include older women with either mobility and/or cognitive difficulties. Robbins-Ruszkowski (2017: 2017-8) noted that 'despite attending U3As in two cities over a period of four years, I never saw anyone in a wheelchair. Very few people used a cane', thereby demonstrating the high likelihood that later-life learning centres will be marked by 'a deep cultural discomfort with what could (or should?) be regarded as the normal human conditions of frailty, (inter)dependence, vulnerability, and transience' (Lamb, Robbins-Ruszkowski, Corwin 2017: 13). At Wls, an age-divide was revealed by the anger of some women when they heard that Denman College was planning to try to attract younger women in the future, and by their concern as to whether the cut in funding would mean that they would no longer be able to afford to enrol on courses at Denman College as they grew older. 


\section{Conclusion}

Although feminist theorising has long played a key role in both adult education and ageing studies, the same cannot be said for the field of older adult learning. One cannot, of course, not acknowledge later-life learning's potential to meet a range of older women's social and emotional needs by mitigating against solitude and loneliness in later life - generally resulting from widowhood, mandatory retirement, health problems, and/or poverty - and helping them to improve their coping strategies. However, this article has questioned whether, in the long run, such an approach is in the best interests of older women. In the research studies reported here, older women learners seemed to have very little awareness of constructions of gender or of feminist consciousness, as the later-life learning centres they were enrolled in neglected to either grapple or embrace any of the inroads made by feminism pedagogy. When they did actually adopt a politically standpoint, as was the case of the WIs, the focus was on injustices faced by younger women, whereby they chose to overlook the agerelated power relations that are embedded and institutionalised in social arenas that in turn have vital consequences for the life chances of older women. Moreover, older women at all times still had to assume or maintain their place or position as (middleclass) women within their family and community (constructed as home makers, carers and supporters), despite the fact that 'since woman is a socially defined and inherently distorted term ... we have no reason to think females have an inherent nature or role' (Saulnier 1996: 174 - italics in original). This resulted in the juxtaposition of the public and private spheres, whereby men and women are allocated to the former and latter, respectively. On the one hand, this ensured that women's and men's activities were treated as mutually exclusive. On the other hand, this had the effect of identifying particular roles and characteristics such as submission, nurturing, and caring as the domain of women, and the roles of leadership and decision-making as the role of men, where the latter are valued and cherished more.

There is no doubt that in an ageing society, organisations such as U3As and WIs have the potential to improve the quality of life of older women and the overall community in which they live. The benefits of membership in such organisations include the ability to develop positive identities that spur and encourage older women to play an active and useful role outside the family and employment avenues. Yet, their role in enabling older women to reach some level of critical consciousness by leading them to reflect on everyday realities and analyse the relationships between personal contexts and the wider social forces of marginalisation is marginal at best. This can only be achieved by means of three strategies (hooks 1994). First, educators should replace the old paradigms of education with a new one that focuses on the individual's experience, along with an acknowledgment of the individual's 


\section{ESEJ / ESSAY}

environment/background. Second, the learning event should focus on educating those who are marginalised with the help of strategies that empower the self and develop leadership skills. Finally, instructional methods should abandon the 'banking' model of education in favour of the development of reflexivity, personal and collective empowerment, and the redistribution of power within the classroom setting. These recommendations, together with this article, should act as a catalyst for feminist initiatives in the field of older adult learning.

\section{References}

Andrews, M. 2015. The Acceptable Face of Feminism: The Women's Institute as a Social Movement. London: Lawrence and Wishart Limited.

Beaumont, C. 2018. The Acceptable Face of Feminism: The Women's Institute as a Social Movement / The WI: A Century in the Making. Women's History Review 27 (3): 500-503, https://doi.org/10.1080/09612025.2018.1424751.

Belenky, M. F., B. McVicker Clinchy, N. R. Goldberger, J. M. Tarule. 1986. Women's Ways of Knowing. New York: Basic Books.

Bernstein, B. 1996. Pedagogy, Symbolic Control and Identity. London: Taylor and Francis.

Bourdieu, P. 1984. Distinction: A Social Critique of the Judgement of Taste. London:

Routledge.

Broecher, J., J. H. Davis, J. F. Painter. 2017. Rediscovering the Political Dimension of the Personal Life Story: Results from an Intergenerational Narrative Learning Project with Older Adults in South Westphalia. International Journal of Lifelong Education 36 (4): 471-485.

Carragher, L., B. Golding. 2015. Older Men as Learners: Irish Men's Sheds as an Intervention. Adult Education Quarterly 65 (2): 152-168, https://doi. org/10.1177/0741713615570894.

Creely E., J. Southcott. 2020. Developing perceived Self-Efficacy in Later Life through Poetry Writing. An Analysis of a U3A Poetry Group of Older Australians. International Journal of Lifelong Education 39 (2): 191-204, https://doi.org/10.1080/02601370.2020.1737589.

Dadzie, S. 1993. Older and Wiser: A Study of Educational Provision for Black and Ethnic Minority Elders. Leicester, England: NIACE.

Etienne, J., S. Jackson. 2011a. Beyond the Home: Informal Learning and Community Participation for older women. Pp. 49-66 in Jackson, S. (ed.). Innovation in Lifelong Learning: Critical Perspectives on Diversity, Participation and Vocational Learning. London: Routledge.

Etienne, J., S. Jackson. 2011b. Lifelong learning in Later Years: Choices and Constraints for Older Women. Pp. 227-244 in Jackson, S., Malcolm, I., Thomas, K. (eds.). Gendered Choices: Learning, Work, Identities in Lifelong Learning. Dordrecht: Springer.

Findsen, B., M. Formosa. 2011. Lifelong Learning in Later Life: A Handbook on Older Adult Learning. Rotherham: Sense Publishers.

Findsen, B., M. Formosa. 2016a. Introduction. Pp. 1-9 in Findsen B., Formosa, M. (eds.). 
International Perspectives on Older Adult Education: Research, Policies, Practices. New York: Springer.

Findsen, B., M. Formosa. 2016b. Concluding Remarks. Pp. 507-519 in Findsen, B., Formosa, M. (eds.). International Perspectives on Older Adult Education: Research, Policies, Practices. New York: Springer.

Formosa, M. 2000. Older Adult Education in a Maltese University of the Third Age: A Critical Perspective. Education and Ageing 15 (3): 315-339.

Formosa, M. 2005. Feminism and Critical Educational Gerontology: An Agenda for Good Practice. Ageing International 30 (4): 396-411, https://doi.org/10.1007/s12126-005-1023-X.

Formosa, M. 2007. A Bourdieusian Interpretation of the University of the Third Age in Malta. Journal of Maltese Education Research 4 (2): 1-16.

Formosa, M. 2012. Education and Older Adults at the University of the Third Age. Educational Gerontology 38 (1): 114-125, https://doi.org/10.1080/03601277.2010.515910.

Formosa, M. 2014. Four Decades of Universities of the Third Age: Past, Present, and Future. Ageing \& Society 34 (1): 42-66, https://doi.org/10.1017/SS0144686x12000797.

Formosa, M. 2015. Ageing Policy in Malta: Issues, Policies and Future Trends. San wann: Book Distributors Limited.

Formosa, M. 2019a. Educational Gerontology. In Gu, D., Dupre, M. E. (eds.). Encyclopedia of Gerontology and Population Ageing. Cham, Switzerland: Springer. Retrieved 15/2/21 (https://link.springer.com/content/pdf/10.1007\%2F978-3-319-69892-2_411-1.pdf).

Formosa, M. 2019b. University of the Third Age. In Gu, D., Dupre, M. E. (eds.). Encyclopedia of Gerontology and Population Ageing. Cham: Springer. Retrieved 15/2/21 (https://link. springer.com/content/pdf/10.1007\%2F978-3-319-69892-2_412-1.pdf).

Formosa, M. 2019c. (ed.). The University of the Third Age and Active Ageing: European and Asian-Pacific Perspectives. Cham: Springer.

Formosa, M. 2019d. Third Age Learning for Active Ageing in Malta: Successes and Limitations. Pp. 81-93 in Formosa, M. (ed.). The University of the Third Age and Active Ageing: European and Asian-Pacific Perspectives. Cham: Springer.

Formosa, M. 2019e. Active Ageing through Lifelong Learning: The University of the Third Age. Pp. 3-18 in Formosa, M. (ed.). The University of the Third Age and Active Ageing: European and Asian-Pacific Perspectives. Cham: Springer.

Formosa, M. 2019f. Concluding Remarks and Future Prospects. Pp. 259-272 in M. Formosa (ed.). The University of the Third Age and Active Ageing: European and Asian-Pacific Perspectives. Cham: Springer.

Formosa, M., P. Cassar. 2019. Visual Art Dialogues in Long-Term Care Facilities: An Action Research Study. International Journal of Education and Ageing 5 (1): 23-41.

Formosa, M., R. Galea. 2020. Critical Educational Gerontology at a Senior Centre in Malta: Possibilities and Limitations for Critical Consciousness. Educational Gerontology 46 (2): 59-71, https://doi.org/10.1080/03601277.2020.1711587.

Freire, P. 1970. Pedagogy of the Oppressed. London: Penguin Books.

Hallam, S., A. Creech, 2016. Can Active Music Making Promote Health and Well-Being in Older Citizens? Findings of the Music for Life Project. London Journal of Primary Care 8 (2): 21-25, http://dx.doi.org/10.1080/17571472.2016.1152099. 
Haraway, D. 1985. Manifesto for Cyborgs: Science, Technology and Socialist Feminism in the 1980s. Socialist Review 80 (2): 65-108.

Harold, S. 1992. Education in Later Life: The Case of Older Women. Educational Gerontology 18 (5): 511-527, http://dx.doi.org/10.1080/0360127920180508.

Hiemstra, R. 1993. Older Women's Ways of Learning: Tapping the Full Potential [online]. Paper presented at the University of Nebraska at Omaha Conference on The Enduring Spirit: Women as they Age, Omaha. Retrieved 18/8/20 (https://roghiemstra.com/ unospeech.html).

hooks, b. 1994. Teaching to Transgress. New York: Routledge.

hooks, b. 2000. Feminism is for Everybody. New York: South End Press.

Hooyman, N. R. 2018. A Personal, Professional, and Political Journey as a Feminist Gerontologist. Gender and Age: A Focus on Women. San Francisco, CA: American Society on Aging.

Jackson, S. 2005. When Learning Comes of Age: Continuing Education in Later Life. Journal of Continuing and Adult Education 11 (2): 188-199, https://doi.org/10.7227/JACE.11.2.6. Jackson, S. 2006. Jam, Jerusalem and Calendar Girls: Lifelong Learning and the WI. Studies in the Education of Adults 38 (1): 74-90, https://doi.org/10.1080/02660830.2006.11661 526.

Jackson, S. 2012. 'Lost Ladies': Lifelong Learning and Community Participation for Older Women. Studies in the Education of Adults 44 (1): 21-34, http://dx.doi.org/10.1080/0266 0830.2012 .11661621$.

Kamler, B. 2006. Older Women as Lifelong Learners. Pp. 153-163 in Leathwood, C., Francis, B. (eds.). Gender and Lifelong Learning: Critical Feminist Engagements. London: Routledge.

Lamb, S., J. Robbins-Ruszkowski, I. A. Corwin. 2017. Introduction: Successful Aging as a Twenty-First-Century Obsession. Pp. 1-23 in Lamb, S. (ed.). Successful Aging as

a Contemporary Obsession. New Brunswick: Rutgers University Press.

Lamb, R., E. M. Brady. 2005. Participation in Lifelong Learning Institutes: What Turns Members On? Educational Gerontology 31 (3): 207-224, https://doi. org/10.1080/03601270590900936.

Leathwood, C., B. Francis. 2006. Introduction: Gendering and Lifelong Learning. Pp. 1-5 in Leathwood, C., Francis, B. (eds.). Gender and Lifelong Learning: Critical Feminist Engagements. London: Routledge.

Leavy, P., Harris, A., 2019. Contemporary Feminist Research from Theory to Practice. New York: Guilford Press.

Luke, C., J. Gore. 1992. Feminisms and Critical Pedagogy. New York: Routledge.

Mackowicz, J., J. Wnek-Gozdek. 2016. 'It's Never Too Late to Learn' How Does the Polish U3A Change the Quality of Life for Seniors. Educational Gerontology 42 (3): 186-197, https://doi.org/10.1080/03601277.2015.1085789.

Maher, F., M. Tetreault. 1994. The Feminist Classroom. New York: Basic Books.

Maidment, J., S. Macfarlane. 2011. Older Women and Craft: Extending Educational Horizons in Considering Wellbeing. Social Work Education 30 (6): 700-711, https://doi.or g/10.1080/02615479.2011.586568. 
McFadden, S. H., R. C. Atchley. 2001. (eds.). Learning, Aging, and Other Predicaments. New York: Springer.

Meade, K., J. Walker. 1989. Gender Equality: Issues and Challenges for PreRetirement Education. Educational Gerontology 15 (2): 171-185, https://doi. org/10.1080/0380127890150206.

Midwinter, E. 1984. Universities of the Third Age: English version. Pp. 3-19 in Midwinter, E. (ed.) Mutual Aid Universities. Kent: Croom Helm Ltd.

Narushima, M., J. Liu, N. Diestelkamp. 2013. Motivations and Perceived Benefits of Older Learners in a Public Continuing Education Program: Influence of Gender, Income, and Health. Educational Gerontology 39 (8): 569-584, https://doi.org/10.1080/03601277.201 2.704223.

National Federation of Women's Institutes. 2019. Annual Review 2018-2019. Retrieved 21/1/21 (https://www.thewi.org.uk/media-centre/annual-review).

National Federation of Women's Institutes. 2020. Denman - Our College. Retrieved 21/1/21 (https://www.thewi.org.uk/denman).

National Federation of Women's Institutes. n.d. Denman Comes to You. Retrieved 21/1/21 (https://www.denman.org.uk/).

Patterson, R., S. Moffatt, M. Smith, J. Scott, C. McLoughlin, J. Bell, N. Bell. 2016. Exploring Social Inclusivity within the University of the Third Age (U3A): A Model of Collaborating Research. Ageing \& Society 36 (8): 1580-1603.

Phillips, J., M. Bernard. 2001. Women Ageing: Changing Policy, Changing Practice. Pp. 168-178 in M. Bernard, J. Phillips, L. Machin, V. Harding Davis (eds.). Women Ageing: Challenging identities, Challenging Myths. London: Routledge.

Robbins-Ruszkowski, J. 2017. Aspiring to Activity: Universities of the Third Age, Gardening, and other forms of Living in Postsocialist Poland. Pp. 112-125 in S. Lamb (ed.). Successful Ageing as a Contemporary Obsession: Global Perspectives. New Brunswick, NJ: Rutgers.

Robinson, J. 2012. A Force to Be Reckoned With: A History of the Women's Institute. London: Virago Press Ltd.

Rogers, A. 2006. Lifelong Learning and the Absence of Gender. International Journal of Educational Development 26 (2): 189-208.

Sagebiel, F. 2006. Elder Women and the Emancipative Impact of Life Long Learning in Germany. Pp. 249-367 in Sempruch, K., Willems, K., Shook, L. (eds.). Multiple Marginalities: An Intercultural Dialogue on Gender in Education across Europe and Africa. Frankfurt: Ulrike Helmer Verlag.

Saulnier, C. F. 1996. Feminist Theories and Social Work: Approached and Applications. Binghampton, NY: The Haworth Press.

Skeggs, B. 1997. Formations of Class and Gender. London: Sage.

Third Age Trust. n.d. U3A - Principles and Vision. Retrieved 15/2/21 (https://www.u3a.org. uk/about/vision).

Tisdell, E. J. 1996. Feminist Pedagogies and Adult Learning: Underlying Theory and Emancipatory Perspective. Pp. 307-312 in Proceedings of the 37th Annual Adult Education Research Conference. Tampa, FL: University of South Florida.

Tisdell, E. J. 1998. Postructural Feminist Pedagogies: The Possibilities and Limitations of 


\section{N ESEJ / ESSAY}

a Feminist Emancipatory Adult Learning Theory and Practice. Adult Education Quarterly 48 (3): 139-156, https://doi.org/10.1177/074171369804800302.

Voet, R. 1998. Feminism and Citizenship. London, England: Sage.

Ware, C. 2013. Men and U3A. Retrieved 15/2/21 (https://u3aresearch.org.uk/ documents/55b3bcdb0e99d3ec98cb517b02cae826.pdf).

Wilińska, M. 2016. Proud to be a Woman: Womanhood, Old Age, and Emotions. Journal of Women \& Aging 28 (4): 334-345, https://doi.org/10.1080/08952841.2015.1017431.

Williamson, A. 2000. Gender Issues in Older Adults' Participation in Learning: Viewpoints and Experiences of Learners at the University of the Third Age. Educational Gerontology 26 (1): 49-66, http://dx.doi.org/10.1080/036012700267394.

Withnall, A. 2009. Improving Learning in Later Life. London: Routledge.

Zarestky, J., S. Sisco, G. D. Alston, J. C. Collins. 2019. Adult Learning and Inclusive Feminism: Historical and Contemporary Perspectives on Social Justice and Political Activism. New Horizons in Adult Education \& Human Resource Development 31 (4): 4-17, https://doi. org/10.1002/nha3.20261.

(a) BY-NC Marvin Formosa, 2021.

(c) BY-NC Institute of Sociology of the Czech Academy of Sciences, 2021.

Marvin Formosa PhD is an associate professor at the Department of Gerontology and Dementia Studies, Faculty for Social Wellbeing, University of Malta. He also holds the posts of Chairperson of the National Commission for Active Ageing (Malta) and Director of the International Institute on Ageing United Nations - Malta (INIA). His recent publications include The University of the Third Age and Active Ageing, and Population Ageing in the Middle East and North Africa. Contact e-mail: marvin.formosa@um.edu.mt. 